\title{
The Duce in the Street
}

\author{
Illumination in Fascism
}

NANNI BALTZER

\section{Theatrical Lighting Effects}

Various occurrences of everyday life, especially from the 1920s and 1930s, attest to the attractiveness and fascination of light. Pervasive enthusiasm for theatrical light effects-think of pavilions of electricity at world exhibitions or the works of artists like Man Ray—was promoted by the rapid progress of light technology. It was also this technical progress that was at the roots of photography published in the Rivista Illustrata del 'Popolo d'Italia' in May 1933: "Giuoco di riflettori". Obviously the publishers assumed that the image as such — without captions or any relation to the rest of the journal—would fascinate the reader (see: Figure 1).

The title emphasizes the formal interplay of the light beams, but it might be as well showing an anti aircraft floodlight. As a matter of fact, though, "Giuoco di riflettori" by Hans Finsler was taken as a part of a series of pictures at the "Zürcher Lichtwoche" (Zurich light week). The "Zürcher Lichtwoche" took place in October 1932-a few months before the publication of the photography in the Rivista Illustrata del 'Popolo d'Italia'. Hans Finsler had just emigrated from Halle an der Saale in Germany to Switzerland in order to teach photography at the "Zürcher Kunstgewerbeschule" instead of "Burg Giebichenstein". He thoroughly documented the "Zürcher Lichtwoche". The "Zürcher Lichtwoche" was an elaborate and expensive exhibition. Its aim was to show the new possibilities of electrical light for artistic effects in urban development (see: Figure 2). 
Figure 1: Hans Finsler, "Giuoco di riflettori"

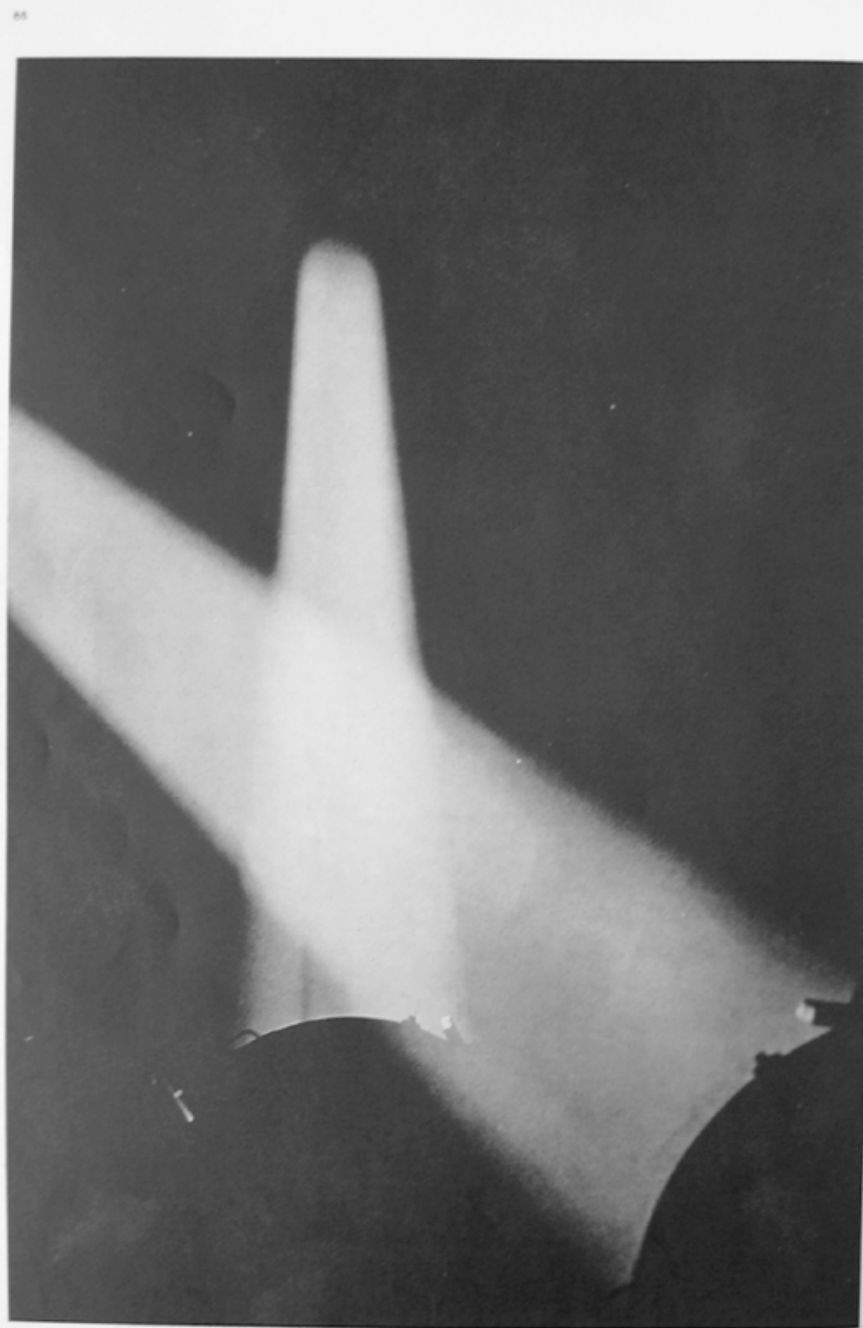

Ginese pi nifleweri

Source: Rivista Illustrata del 'Popolo d'Italia', Mai 1933: 88 
Figure 2: Zürcher Lichtwoche, October $1^{\text {st }}-9^{\text {th }}, 1932$

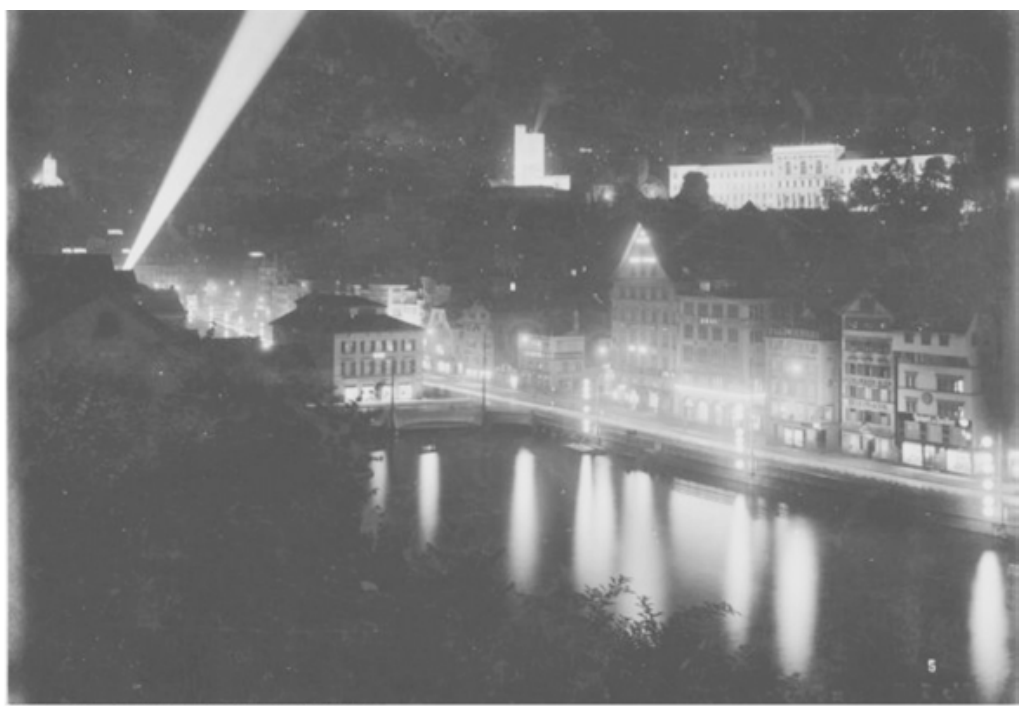

Source: Photoglob

The motto of the "Zürcher Lichtwoche" was therefore: "Technology and art shake hands". Together with technicians and an electric power company, influential contemporary artists like Max Bill or Augusto Giacometti helped planning the exhibition. Besides the exhibition and the contest, though, many other attractions-swimming fountain of light, an amusement park, night excursions, spectacular neon signs and temporarily illuminated streets, buildings and shop windows-drew the public into town at night.

Shortly before the "Zürcher Lichtwoche" in 1931, the book Italia nuova Architettura nuova was published. Virgilio Marchi, a futurist and friend of Tommaso Marinetti, but also a writer, an architect and movie set designer of about sixty films and numerous plays, was asking the book's readers why the festive illumination of church facades did not transfer to profane architecture. Marchi advocated the illumination of urban spaces as carried out in Zürich shortly after.

Marchi however had another goal than the city council of Zürich: by using floodlights to send light beams to the sky and God, he hoped to "elevate the soul into the realm of mysticism". ${ }^{1}$ Not that Marchi's thoughts

1 | "Al fine di un articolo riguardante la scenotecnica delle rappresentazioni sacre all'aperto mi domandavo: 'Perché non si deve fare della luce moderna un inno che dai riflettori salga in alto come da tanti turriboli d'argento?' lo intendevo 
were new. The idea of linking the Divine (heavenly) with the earthly by means of light is many thousand years old. It can be traced back to the ancient Egypt where the apex of the obelisk was coated with gold, so that the sunlight would reflect and make a connection to the sun god through light. Interesting about Marchi's thoughts is his idea of secularization combined with the desire for mysticism. He puts sacred events on a level with theater and profane architecture which require both drama and mysticism. Surely, the illumination of St. Peter's Basilica with floodlights and hundreds of torches a few years before the publication of Marchi's article-during the Anno Santo 1925-must have been a good example for both drama and mysticism (Marra 2000: 159).

Mysticism was an important reason for the success of all of the following examples of fascist illuminations, although its working was all but explicit. Mussolini himself uttered his opinion regarding this crucial, but elusive ingredient in 1932, when he said to Emil Ludwig, the noted German biographer: "The mystical and the political side depend on each other. The first is dry without the second; the second without the first decays in the flags' wind" (Ludwig 1932: 123-124; transl. by the author).

The Fascists knew how to use the mystical power of light and they did so on several occasions, for example on the anniversary of the March on Rome, October $28^{\text {th }}$, or during the "Anniversario della Vittoria", November $4^{\text {th }}$ (see the photo documentation in L'Illustrazione italiana, November $12^{\text {th }}, 1933$, on page 765$)$. During my research I descovered another example for the use of theatrical light effects which, at the first glance, had nothing to do with politics or religion. For the opening of the exhibition "Esposizione Aeronautica Italiana", floodlights were installed on the Milano Dome square to illuminate the artificial wafts of mist (see: Figure 3 and 4$)^{2}$

Even though these kind of illumination was a popular, eye-catching

dare alla luce elettrica un senso mistico [... ] come si fa con la luce medesima sul teatro dramatico. S'intende che l'architettura religiosa e non religiosa é implicata nel problema, come fonte di partenza o come schermo di arrivo. L'osservazione veniva da certe illuminazioni di chiese per le grandi festività. [... ] il fine dell'illuminazione ha un che il teatrale analogo a quella della luce nelle sacre rappresentazioni" (Marchi, "Elevare l'anima trascinandola nel regno mistico.", in Marchi 1997: 71; transl. by the author.).

2 | The project not only reminds one of the present-day artificial stagings of nature as Olafur Eliasson's artifical evening sun in a veil of mist, in the Tate Modern, to where the visitors could escape the London winter, but even more so of baroque spectacles. In 1794, such a spectacle took place on the "Felseninsel" in the Wörlitz Park of Count Leopold III, Friedrich Franz von Anhalt-Dessau, when the volcano, created by Friedrich Wilhelm von Erdmannsdorff, smoked, glowed and spat. See: 
Figure 3: Atmospheric "mis en scène", Dome square, Milan, on the occasion of the opening of the Esposizione aeronautica italiana, June $16^{\text {th }}, 1934$



Source: AEM (Azienda Elettrica Municipale), Archivio Fotografico

and an important instrument of fascist propaganda, it was scarcely discussed in scientific literature; on the rare occasions it was, its analysis was dissolved in a greater research field of attempted sacredness of Fascism (Randone 1933: 41-45). ${ }^{3}$ This work is the first thorough research on illumination in Fascism (see: Baltzer 2009). For the sake of explicitness, I will specifically focus on just one example.

Vorstand der Kulturstiftung DessauWörlitz 2005; for the festivities of the re-opening of the restored island Stein in September 2005, several eruptions were staged.

3 | In Gentile's standard work concerning the sacralisation of Fascism, the light effects on the Milan Dom Square are briefly mentioned (Gentile 2003: 153-155). From 1926, according to Gentile, the celebrations always followed a similar pattern, they were organised by the Fascist Party and executed under the control of the Police. 
Figure 4: Atmospheric "mis en scène", Dome square, Milan, on the occasion of the opening of the Esposizione aeronautica italiana, June $16^{\text {th }}, 1934$



Source: AEM (Azienda Elettrica Municipale), Archivio Fotografico

\section{Illuminations on October $\mathbf{2 8}^{\text {th }}$}

Since 1926, the anniversary of the march to Rome on October $28^{\text {th }}, 1922$ was giving the population a reason for an annual celebration. Fascist organisations, like militia, unions, youth organisations, as well as widows and orphans, the decorated an the wounded took their part in the rigidly organised routine of the day. The celebration was given a military note in order to cater to the population's taste: the "Foglio d'ordini" of the fascist party highlighted "the idea that at the base of the fascist revolution stood the military, which guaranteed life and progress to every citizen". ${ }^{4}$

A strict schedule shaped the festive occasion: the morning was meant for the religiously inspired part with fascist rites, the commemoration of the fallen, the parades and the speech of the Duce, which was transmitted by Radio to every corner of Italy. The afternoon belonged to the popular fête with dancing, music and excursions to the countryside. Fi-

4 | PNF, "Foglio d'ordini" (10, October $\left.9^{\text {th }}, 1926\right)$, here cit. after Gentile 2003 : 152-153: "[... ] per dare a tutti 'l'idea della formidabile compagine di forze che stanno alla base della Rivoluzione Fascista e ne garantiscono contro chiunque la vita e lo sviluppo". 
nally, in the presence of Mussolini, a military parade including airplane squadrons and deployment of the fascist formations would take place.

All over Italy, fascists assembled in the evening to commemorate their fallen colleagues; as for the general public, son et lumière was another important part of the program. In all the larger Italian cities there was a screening of films in honour of Mussolini, complemented by projections of fascist slogans (such as "W il Duce") and symbols ("fascio"), lighting of roads and public squares, illumination of public buildings (decorated with flags), marches of torch-carriers through the streets and fires on the hill (Gentile 2003: 152-155). As we will see, city centres were transformed by illuminated ephemeral structures into a veritable "theatre of light".

\section{Milano, October 28 ${ }^{\text {th }}, 1933$}

In the following, I will concentrate on one of these "illuminazoni", namely the one that took place in the evening of October $28^{\text {th }}, 1933$, in Milano. On the anniversary of the march to Rome, L'Illustrazione italiana reported, "the crowds flocked to the Dome Square in order to watch the illumination, unimpressed by the pouring rain". ${ }^{5}$ Here, the local electricity station (Azienda Elettrica Municipale) had transformed the Dome Square with the help of colossal candelabras and flowers into a giardino luminoso (see: Figure 5 and 6).

The illuminations in each year were similar to the ones a year before. In 1932, the monumental writing DUX was projected onto Piazza del Duomo. In 1934 fountains were transformed into illuminated cakes, and in 1936 the the monumental light inscription "W IL DUCE" "FONDATORE DEL'IMPERO" embellished the fronts of the surrounding palazzi and the arch of the Gallerie Vittorio Emmanuele II (see: Figures 7, 8 and 9). (The reason for this slogan originated on May $5^{\text {th }}, 1936$ when Italian army conquered Addis Abeba, and four days later Mussolini proclaimed the Italian Emporium).

What makes the illuminazioni of the year 1933 especially interesting is an approximately thirty meter high, square-edged black and white portrait of Mussolini, which was attached to the resplendent façade

5 | "La folla [... e è accorsa la sera del 28 ottobre, sfidando l'acqua torrenziale, ad ammirare l'illuminazione della Piazza del Duomo.", in: L'lllustrazione italiana, (November 12 $2^{\text {th }}, 1933$ : 765 ; transl. by the author).

Giorgio Di Genova authenticates the portrait already in 1922 and 1923 in Numero, respectively in 420 . Somewhat later, the same portrait can be found as a decoration on a ceramic plate, approx. 1926, anonymous (di Genova 1997: 15, 84). 
Figure 5: Installation of the illumination on the occasion of the anniversary of the March on Rome, October $28^{\text {th }}, 1933$

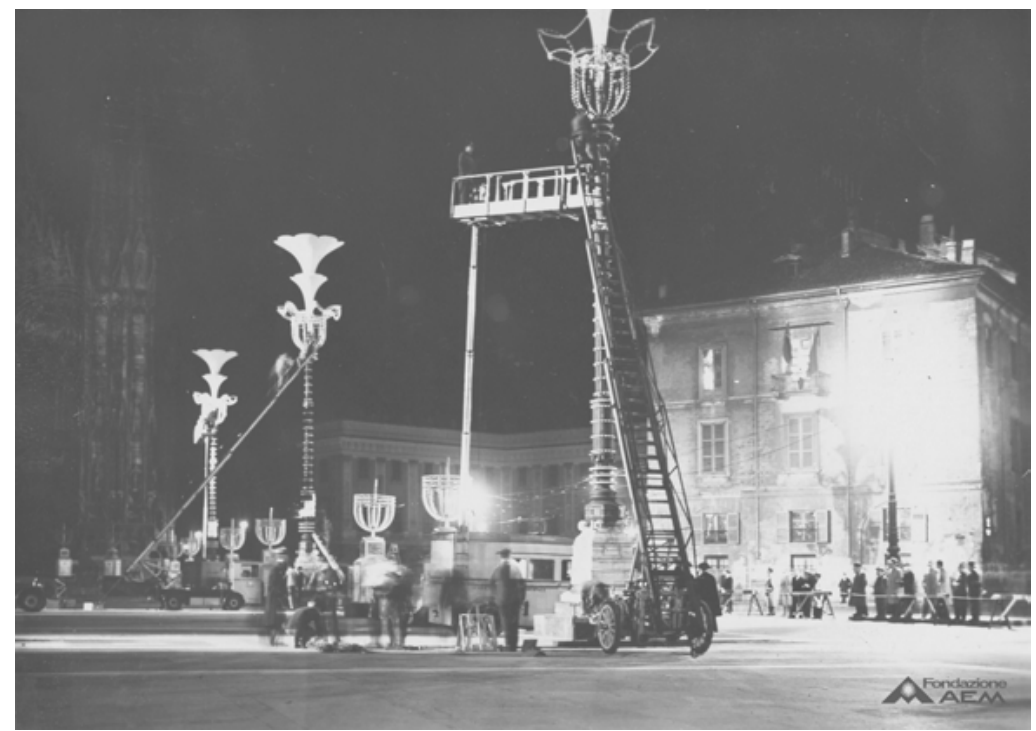

Source: AEM (Azienda Elettrica Municipale), Archivio Fotografico

of the Milan Cathedral, and, as part of the evening illuminations, was highlighted by floodlights (see: Figure 10).

With his usual piercing look, but strangely un-statesmanlike, the Duce looked his people in the eyes. Even within the very wide stylistic range of Duce portraits, this portrait is unusual (Bardi 1933: 5; see: Figure 11). ${ }^{6}$ It can be found in periodicals of the early twenties and even on a ceramic plate (around 1926) which with its inscription points at the total absence of sfumature-nuances, stating on the edge of the plate "l'uomo che non ammette sfumature/o bianco nero/con noi o contro di noi". ("The man, who does not allow shades of grey/either black or white/with us or against us”).

The portrait could have its origin in stencil printing normally used for pavement graffiti (see: Figure 12). The remaining images of the portrait on the façade of the cathedral invite the assumption that it is a painted cardboard taken from a photographic copy, which was illuminated by floodlighting at twilight (see: Figure 13).

Unfortunately we cannot learn much more from the contemporary

6 | Should one interpret Mussolini's piercing look as "seeing-eye"? See the interpretation of general Moshe Dayan's look on the battlefield-in the direction of the viewer of the photograph—by Otto Karl Werckmeister (2005: 26). 
reports because they mention only overall "illuminazioni" and do not refer to any technical details. As far as I know, the whole scenery was unique; never before or after a portrait of Mussolini was shown on a church façade. ${ }^{7}$

The Cathedral Square as a lieu de spectacle was an inviting space for mass gatherings, being the locus of unity and division since early days of Milan not just as a geographical centre in a town, built in concentric circles, but also in economic, social and cultural respects: even today the medieval Broletto, the seat of worldly power and justice, and the Opera (the Teatro alla Scala) stand immediately next to the Cathedral Square. The Square is mainly bordered by the Palazzo Carminati, the Portici Meridionali resp. Settentrionali with the archway of the gallerie Vittorio Emanuele II. The manica lunga (long sleeve) of the Palazzo Reale stood on the opposite side until 1933 and was later replaced by the Aregenario, the portal-like fascist building.

With clear borders on all four sides the Cathedral Square fulfils a basic requirement for hosting compact mass gatherings, as was formulated by Franz Dröge and Michael Müller in their work Power of Beauty (1995):

7 | At least, I could not make out another case, neither in sources nor in secondary literature. The portrait alone, without the church façade in the background, was presented again: in November 1933 in Ascoli Piena (a piece of cardboard or some kind of sheet). In baroque times, churches were, under certain circumstances, certainly used as a background for non-ecclesiastical events, e.g. on the occasion of a birth, a wedding or a death, and included in the organisation of festivities (parades). But Elisabeth Kieven points out (e-mail to the author, November $23^{\text {rd }}, 2008$ ) that on the occasion of canonisations, the façades were decorated with scenes from the life of the saints, on the other hand, in honour of secular rulers, coats of arms and emblems were part of festive decorations on façades. There are no portraits of secular rulers known on church façades. The adornment on the occasion of the birth of the french Dauphin by Gian Lorenzo Bernini (together with Jean Paul Schor), an ephemeral construction which extend along the incline from the Piazza di Spagna up to the façade of the Trinità dei Monti, with the central piece adorned by a large dolphin as a symbol for the successor to the throne, is well known. But the difference in the case described by me consists of the fact that, in Fascism, the church façade was usurped for an event which was completely independent from the Church, whereas in baroque times the Church was an integral part of the festivities. Regarding ephemeral architecture of festivities, see: Kessel 1995. Regarding the inclusion of the façade into the festivities see Boiteux, "Fêtes et traditions espagnoles à Rome au XVIle siècle" (Fagiolo and Madonna 1992: 117-134) and Montserrat Moli Frigola, "Donne, candele, lacrime e morte: funerali di regine spagnole nell'Italia del Seicento" (Fagiolo and Madonna 1992: 135-158). Further to festive architecture in baroque times see also: Fagiolo and Spagnesi 1982; Maurizio e Marcello Fagiolo dell'Arco 1967. Unfortunately, the new publication of Bonnemaison and Macy (2008), in this context is unprofitable. 
"It [the architecture] encloses the mass, which may not dissolve" (Dröge and Müller 1995: 321). The Piazza del Duomo is not only ideal for mass meetings, it is also unique Virgilio Vercelloni (1989) says: "Due to the failure of the Bonaparte Forum, the dome square remained the only significant urban space where crowds could gather. From the union of Italy until the development of new means of communication in the past decades the dome square continued to be the only place, where political and religious events could take place. During Fascism it was the place for mass rites" (see: Figure 14). ${ }^{8}$

\section{Space through Light}

It is a common knowledge that light installations for the effective staging of mass marches became well known due to their prevalence in Nazi Germany, but it was already in 1936 that Albert Speer's "Lichtdom" contributed to the dramatic techniques of the Reichsparteitage on the Nurnberg Zeppelin field. In Italy, on the contrary, the light had already been used for several years as an unalienable part of propaganda events. True, the effect and power of the "Lichtdom" were incomparably stronger than that of the Italians (see: Figure 15). ${ }^{9}$ But Speer built a new closed space and had not illuminated an existing building with the floodlight beams which shone for several kilometres in the night sky.

Speer himself wrote about the occurence: "The sharply defined 130 Rays, put around the field in distances of only 12 meters, were visible up to an altitude of six to eight kilometres and melt up there into a shining expanse. This resulted in an impression of a huge space, in which the single beams appeared to be gigantic pillars of endlessly high outer walls" (Speer 1969: 71). Speer's light domes tied people together and thus prevented the masses from fraying and disintegration. ${ }^{10}$ What the

8| "Il fallimento del progreto giacobino di crere il Foro Bonaparte [... ], fa si che la piazza del Duomo conserviil significato di unico luogo urbano deputato ad accogliere I riunione di massa. Dall'Unità d'Italie sino alla diffusione dei nuovi strumenti di comunicazione degli ultimi decenni, la piazza del Duomo resta il solo contenitore capace di ospitare le grande manifestazione politiche e religiose. Durante gli anni del fascismo al potere è il luogo deputato per i suoi rit di massa" (Vercelloni 1989: 55 ; transl. by the author).

9 | Regarding the idea, the planning and the execution of the light dome, see: Krauter 1997; the work includes a good overview of the reception of Speer's light architecture before, resp. after 1945.

10 | "[Die Begrenzung der Masse] ist neben der Erzeugung der mystischen Stimmung auch die Aufgabe des Lichtdoms" (Dröge and Müller 1995: 321). 
architecture of the dome square guaranteed in Milano, was constructed on the Zeppelin field in the shape of a light dome: the light formed an immaterial wall. Such physical materials as stone and glass were replaced by the architecture of light: this new building material replaced both the church-room and the candlelight and produced a semi-religious atmosphere. The sheer grandeur of the light-dome generated a "depersonalisation of the human being” (Speer 1979: 42), as Albert Speer stated. More than that: "[...] the creation of the so-called 'light-dome' in Nurnberg was for him [Hitler] - and for me [Speer] a culmination of making an impression on human beings, especially from a political view, with the goal of categorization and subordination of man-in order to eliminate his personality" (Speer 1979: 30-31; emphasis NB). ${ }^{11}$ The fials of the cathedral of light pointed into the Divine night sky, and the mystical mood contributed, in its turn, to making the masses susceptible to the National Socialist message.

The use of light for propagandistic means is thus common to both dictatorships is. In both régimes, the light contributes, as a symbol of the Divine, to the sacralization of profane events. ${ }^{12}$ Whereas on the Zeppelin-field the sacral architecture was constructed by light, fascism used the church façade-or so it seems — solely as a carrier for the gigantic portrait of the Duce. But behind the temporary occupation of the church façade by the fascist state stood more than a mere pragmatism, as I will demonstrate shortly.

\section{Sacralisation of Fascism}

Just as equally important as the unification of the masses appeared to be their ordering, given in the Italian case by the portrait of Mussolini. The masses, as stated by Elias Canetti, exist as long as they move in uniformity into a determined direction. "The direction which is common to all members fortifies the feeling of equality. [...] For [...] the existence [of the masses], the direction is an absolute necessity. The fear of disintegration, which always plays an active part, makes it possible to direct

11 | Speer's light architecture did not find any direct following in Italy. One building, however, appears to be a reminiscence of Speer's light architecture. The italian pavillion of the Roman architect Marcello Piacentini at the World exhibition in Paris 1937, situated directly on the Seine, was illuminated at night in such a way that the almost cubic façade, structured by loggias, doubled in size and was turned into a lighthouse by the reflection in the river.

12 | See also Marchi, "Architetture pirotecniche", in: Marchi 1997: 71-79. 
them unto any kind of target. The masses exist, as long as they have an unreachable target" (Canetti 1985: 26-27). ${ }^{13}$ In the discussed case, the unreachable target dominated the façade of the dome: Mussolini, the outstanding personification of Fascism, was worshipped like a God after years of single-minded propaganda.

Gustave Le Bon, whose publication "Psychology of the masses" (1911) can be regarded as a kind of working instruction for the domination of the masses, opined that an individual in the crowd could only be impressed if the religious basis is provided (Le Bon 1982: 36). And further: "For the masses, either one has to be God or one is nothing" (Le Bon 1982: 48). Mussolini seemed to carry out these instructions, when in 1926 he prepared the apotheosis of Fascism and his own person with the following motto: "Fascism is not only a party, but a regime, not only a regime, but a faith, not just a faith, but a religion that captivates the laborers". 14

Part of the fascist, quasi-religious rites were for instance Decalogues and actual prayers for and/or to the leader. ${ }^{15}$ Mussolini counted, by the supernatural abilities attested to him, as the person to be addressed with problems of any kind. One of the authors of numerous fascist prayers, Alessandro Melchiori, issued arecommendation: "If you, comrade, experience bitter moments due to miserable earthly circumstances, raise your spirit and say your prayer" 16 _ not to god, but to and for the Duce, as Melchiori expounds in a "Prayer to the Duce":

13 | Gustave Le Bon already formulated: "under certain circumstances and only under these circumstances, the gathering of people possesses new, completely different qualities from the qualities of the single people who form this gathering. The conscious personality fades, the feelings and thoughts of all the individuals are orientated towards the same direction" (Le Bon 1982: 10).

14 | "Il Fascismo non è soltanto un partito, è un regime, non è soltanto un regime ma una fede, non è soltanto una fede ma una religione che sta conquistando le masse lavoratrici del popolo italiano" (Mussolini's speech in Pesaro, August $8^{\text {th }}, 1926$, PNF 1939: 35).

15 | With regard to the appropriation of christian symbols by Fascism reference is made at this point to the new Fascist chronology which begins, instead with the birth of Christ, with the march on Rome on October $28^{\text {th }}, 1922$, and the "Befana", i.e. the feast of the Epiphany on which occasion presents are given to the children, which was renamed in 1928 into "Befana fascista": 1931 the "Befana fascista" was moved from January $6^{\text {th }}$ to Christmas Day, whereupon the celebration was named "Natale del Duce". See: Gentile 2003: 156.

16 | "E allora, o camerata, quando tu hai [...] degli istanti di amarezza per piccole e miserevoli cose terrene, esalta il tuo spirito ed elèva la tua preghiera" (Melchiori 1935: 182; here after Galeotti 2000: 30). 


\section{"Prayer to the Duce}

For you, oh Duce, who is the life, the hope, the assurance for a new Italy, For you, oh Duce, who makes hardship easy and the lowliest service an honour, For you, oh Duce who sees and hears everything as a leader due to your mind, as a father due to your heart,

You, whom I love more than anything else in the world

You, who has given me a strong, formidable and great fatherland,

You, to whom, for the joy of a moment, for a smile from the distance, for the certainty that you will hear me, I offer, in all humility, my life, oh Duce."17

In these prayers Mussolini not only equated with God, but was put in His place, as also in the sculpture "The empire arises from the duce's mind" by Ferruccio Vecchi, “L'Impero balza dalla mente del Duce”, (1939-40) which was shown at the Biennale in Venice in 1940. A gigantic head (Mussolini) rising from a naked muscular-martial figure aremed with sword and fascio. The reference to the features of Mussolini is unmistakable: the creator is the Maker of himself, combining fascism and the Emporium (see: Figure 16). ${ }^{18}$

Lutz Klinkhammer, in his study of the relationship between the fascist liturgy and the Catholic religion, denies the existence of a "feda fascista" (fascist faith) (Klinkhammer 2003: 73-90) ${ }^{19}$ comparable to the catholic faith. Klinkhammer's further thesis-that Mussolini has never been attributed extraterrestrial qualities-must be rejected: his statement is at variance not only with the afore-mentioned "Prayer to the Duce", but also with numerous statements putting Mussolini on God's level, as in the "Creed of Belief" of Massimo Bontempelli (Galeotti 2000: 19-26). Bontempelli (1878-1960), a writer, dramatist, critic and founder (together with Curzio Malaparte) of the literary journal 900, was in the 1930's a highly influential personality in the Italian culture. Under the title of "literary politics" Bontempelli published personal dogma-statements, reminiscent of the mechanistic belief in progress espoused by futurists:

17 | "Preghiera al Duce/Per Te, o Duce, che sei la vita, la speranza, la certezza dell'Italia nuova; per Te, o Duce, che rendi lieve la fatica, e nobile ogni più umile servizio; per Te, o Duce, che tutto vedi e tutto senti col Tuo genio di Capo e col Tuo cuore di Padre; a Te che io amo più di ogni altra cosa al mondo; a Te che m'hai dato una Patria forte, temuta e grande; a Te, per la gioia di un istante, per un sorriso intravisto di lontano, per la certezza che Tu m'odi, io offro in umiltà la mia vita, o Duce" (Melchiori 1935: 182; here after Galeotti 2000: 30).

18 | Not to be confused with the sculpture "The Fascism" by Aroldo Bellini, a gigantic figure on a pedestal resembling Mussolini. This, appr. 100 meters high, was to have been errected behind the Foro Mussolini on Monte Mario. See: Benton 1996: 126-127.

19 | Although I think that a Fascist faith existed, one can hardly speak of Fascism as a religion. 
" $1^{\circ} \mathrm{I}$ believe in fascism as a daily revolution, $2^{\circ} \mathrm{I}$ believe in Rome-Italy as motor and balance for Europe, $3^{\circ} \mathrm{I}$ believe in the passion, the unforeseen and the war, $4^{\circ} \mathrm{I}$ believe in Mussolini, the God without prophets." ${ }^{20}$

Mussolini thus required neither herald nor mediator, because, as it is clear from Bontempelli's creed of belief, the Duce was himself the God on earth, reminding of Le Bon's statement "For the masses one must [...] be God". 21

\section{Religion as the Foundation for Totalitarian Regimes}

Mussolini puts himself, his regime and the City of Rome on the same level as the Impero of the ancient emperors and the Roma restaurata of the popes. In order to anchor the image of a seamless, continual tradition in the collective memory of the population, the propaganda machinery of Fascism had explicitly and extensively drawn upon the repertoire of its mighty predecessors. The recourse was taken either to the antiquity or to the forms, rituals and symbols of Catholicism. ${ }^{22}$ Suffice to mention "Befana" - the Feast of Epiphany on which presents are handed over to the children - which was renamed in 1928 to "Befana fascista". In 1931, the "Befana fascista" was shifted from January $6^{\text {th }}$ to the Christmas Day, whereupon the Feast was baptized "Natale del Duce".

By integrating religious elements into its propaganda, fascism could lean upon positively charged acts and pictures which for had been anchored for centuries in the collective memory of the people. In that

20 | "La mia fede fascista io per mio conto me la sono tradotta così: $1^{\circ}$ Credo nel Fascismo come rivoluzione quotidiana; $2^{\circ}$ Credo in Roma-Italia motrice ed equilibratrice d'Europa; $3^{\circ}$ Credo nella passione, nella improvvisazione e nella guerra; $4^{\circ}$ Credo in Mussolini Dio senza profeti" (Massimo Bontempelli, "Politica letteraria", in: Quaderni di segnalazione 1933 III (Aug.-Sept.): 28, here cit. after: Galeotti 2000: 28).

21 In Biondi (1973: 217), God still exists next to Mussolini, but then it states regarding the Duce: "Discese a Roma: il terzo giorno ristabili lo Stato, [...]"-the image of the creator could not be more obvious.

22 | 'E un equivoco fu il 'mussolinismo', con gli anni. Capo e popolo s'intesero di prim'acchìto, ma rimasero a questo. II regìme, che non volle essere 'rappresentativo', si fermò alla 'rappresentazione'. Cessò di essere un regìme, per divenire una regìa. La mimica spontanea dell'uomo si fissò nei gesti, che la folla amava. Si sono viste folle chiederglieli, questi gesti; e estasiarsene. II 'mussolinismo' era divenuto un rito, una liturgìa" (Giuseppe Bottai, entry in diary on March $3^{\text {rd }}$, 1946, in: Bottai 1988: 317). Literature regarding the sacralisation of Fascism (selection): Gentile 2003; Le Bon 1982; Klinkhammer 2003: 73-90. Primarily regarding Germany, marginally also regarding Italy, see: Mosse 1993. 
way totalitarian regimes, like Fascism, develop, in the words of Matthias Behrens, "[...] a myth and a cultist life (rites, liturgy, sacral language, music); both are to help with the realization of the ideological, moral, summoning action and cause an intensity of the experience corresponding with the totalitarian demands" (Behrens 1997: 260).

\section{Excursus \\ Moscow}

With regard to this phenomenon of taking over images and rituals anchored in the people as a basis of new innovations, I should like to make a short side trip to Moscow. In the early 1930s, on the May $1^{\text {st }}$ of every year, the monumental portraits of Lenin and Stalin (sometimes of Marx and Engels as well), as large as 25 meters high, were displayed and illuminated with floodlights in the evening (see: Figure 17). ${ }^{23}$

Here on this picture, we see Gustav Klutsis's monumental photographies of Lenin and Stalin, made for May ${ }^{\text {st }}$, 1932, in nocturnal illumination in front of the Hotel Metropol on the Sverdlov Square in Moscow. Between the figures, a model of the Dnjepr barrage can be recognised. On the reproduction of the dam Lenin's slogan can be read: "Communism is Soviet Power plus the electrification of the whole country" (Taylor 1996: 249).

Brandon Taylor describes the figures in his essay "Concentrated photographic effects, painting and iconic elevation” (Taylor 1996: 249-252) as the contemporary forms of the traditional Russian icons. One has to imagine this graphically: the figures about 25 meters high depicted on the photo boards, are traced back to the small icons (see: Figure 18).

In fact, both the Soviet leaders and, occasionally, saints are depicted as complete figures facing each other. Position and status of the tablets held in the hand of the saints are compared by Taylor to the writings on the coffer-dam wall. Taylor sees major affinities between the giant communist photos and icons in the "great potential for public effect" and the "auratic elevation of the two leaders" (Taylor 1996: 251). To that end, he writes: "The modern variation shows both Soviet leaders elevated to saints and, insinuated by the unfurling liturgy of electrification in their

$23 \mid$ The full body portraits of Lenin and Stalin measured appr. $25 \mathrm{~m} \times 10 \mathrm{~m}$; they are put together from innumerable single foto tiles, each measuring $50 \times 60 \mathrm{~cm}$. The whole installation was put up by 200 workers, photo technicians, retouche specialists, statics specialists, etc. see: Taylor 1996: 249. 
midst, in a figurative as well as a literal sense to be in possession of power through the word" (Taylor 1996).

The reason for seeing parallelisms in icons and fascist visuality lies obviously in the potential of these representations to serve as a foundation for a regime in construction. The paraphrasing of the well-known form leads at the same time to the communication of the rituals associated therewith. If one considers, consequently, the icons as a connecting link between the viewer and the portrayed divinities, that endows the gigantic photo figures with the meanings from the divine domain.

It can hardly be doubted that the object of the monumental photographies lies in the admiration, veneration and stylization of the superhumanness (or superhuman greatness) of the persons depicted. Hence, communism makes use of the discourse of the Orthodox Church to transfer the religious practices and effects-such as veneration and beliefonto politics.

\section{The Portrait of the Duce on the Church Façade Fascism and Catholicism}

It is clear that the phenomenon of the sacralisation of politics does not confine itself to Mussolini's Italy, but the direct competition between Mussolini and the pope has some highly specific outcomes. "The Duce is always right" 24 was a standard saying, and his absolute domination, not unusual in dictatorships-had never been contested publicly. The only nationwide counterpart that Mussolini had to cope with was the Pope who resided in the immediate neighbourhood of Mussolini. In catholic Italy, especially in papal Rome, the rivalry was omnipresent and acute; Mussolinis' claim to power did not stop at the borders of the secular power.

Nevertheless, (and notwithstanding the dictum "Fascism is a religion”), the Mussolini regime can hardly be spoken of as a religion, as Emilio Gentile proposed (Ufficio Propaganda del Partito Nazionale Fascista 1923: 7). Rather, on is tempted to agree with Alexander Nützenadel that the adoption of religious rituals and symbols had been a "superficial adaptation" and not "the formation of independent religious faith contents" (Nützenadel 2000: 128).

24 | The sentence can originally be found in "Endecalogo" by Leo Longanesi from 1926 and became, in the following years, the most widely circulated catch phrase (decalogue) of Fascism. 
Without discussing the thesis of Nützenadel, formulated retrospectively, I would like to show that the Portrait of the Duce on the façade of the Dome of Milan was first of all a contemporary attempt to produce the new faith content by means of a "superficial adaptation" in the literal sense of the word (see: Figure 19).

From the forecourt over the entrance area up to the altar at the church crossing the room continually gains in sacral importance. This promenade architecturale, normally perambulated by church-goers (from the square through the door into the church interior, then through the nave to the crossing) is reduced in our example to the relationship between the dome square and the portrait applied to the façade.

In this way, both the sacral message of the church-interior and the one of the façade become irrelevant; the spatial apogee of the sacral hierarchy is shifted from the altar to the forecourt: here resides Mussolini, here are the people who capture from the necessary distance the monumental portrait of the leader at his height. Here, on the parvis - the word used both for the paradise and for the forecourt of the dome, the mass faces the leader and, as one could say with Dröge and Müller, recognises itself in him: "Architecture is the counterpart of the mass, in which it reflets itself and recognises itself". 25

The sacral iconographic program of the dome-façade was superimposed by the portrait of the Duce. Therewith, the secular iconography steps into the immediate neighbourhood of the religious one. The importance of this fascist act lays in transferring religious images onto profane context, using them as a foundation, but also as a legitimation for the relatively young regime.

It is clear that Fascism could never displace Catholic faith. Likewise, for Mussolini it must have been clear that a frontal attack on the church would be fruitless if not outright counter-productive. At least some profit should have been made from pictures of the catholic religion, though, so that the faith in Fascism, incapable of replacing catholic faith, would at least stand on a par with it. In our case this equality was embodied with the help of an icon of the Catholic church on it-the Milanese Dome: for a moment, the two powers were literally on the same level (Taylor 1996: 249-252).

The light-photo-montage in Milan shows clearly that Mussolini, despite the Lateran treaties of 1929 which declared Catholicism the state

25 | "Die Architektur ist das Gegenüber der Masse, in dem sie sich spiegelt und erkennt" (Dröge and Müller 1995: 321). 
religion of Italy, was not prepared to leave to the Catholic Church its terrain without benefiting from it.

\section{References}

Baltzer, N. 2009. Fotomontage im Kontext faschistischer Propaganda im Italien der Dreissigerjahre, PhD. Universität Zürich 2009 (publication scheduled for 2010).

Bardi, P. M. 1933 “Origini”. Quadrante (October): 5.

Behrens, M. 1997. "Politische Religion”-eine Religion? Bemerkungen zum Religionsbegriff. In “Totalitarismus” und "Politische Religionen”. Konzepte des Diktaturvergleichs. Volume 2, edited by H. Maier and M. Schäfer, 249-269. Paderborn: Schöningh.

Benton, T. 1996. Das römische Reich ersteht wieder. In Kunst und Macht im Europa der Diktatoren 1930 bis 1945, edited by D. Ades, T. Benton, D. Elliot and I. B. White, 120-129. Stuttgart: Oktagon.

Biondi, D. 1973. La fabbrica del Duce. Florenz: Vallecchi.

Bon, G. Le. [1911] 1982. Psychologie der Massen (15 ${ }^{\text {th }}$ Edition). Stuttgart: Kröner.

Bonnemaison, S. and C. Macy (editors). 2008. Festival Architecture. London: Routledge.

Bottai, G. 1988. Diario 1944-1948, edited by G. B. Guerri. Mailand: Rizzoli.

Canetti, E. [1960] 1985. Masse und Macht. Frankfurt am Main: Fischer.

Centrum Industriekultur Nürnberg (editor). 1992. Kulissen der Gewalt. Das Reichsparteitagsgelände in Nürnberg. München: Irisiana.

Dröge, F. and M. Müller. 1995. Macht der Schönheit. Hamburg: eva. Fagiolo dell'Arco, M and M. 1967. Bernini. Una introduzione al gran teatro del barocco. Rome: Bulzoni.

Fagiolo, M. and G. Spagnesi (editors). 1982. Immagini del barocco. Bernini e la cultura del Seicento. Rome: Istituto della Enciclopedia Italiana.

Fagiolo, M. and M. L. Madonna (editors). 1992. Il barocco romano e l'Europa. Rome: Istituto Poligrafico e Zecca dello Stato, Libreria dello Stato.

Galeotti, C. 2000. Mussolini ha sempre ragione. I decaloghi del fascismo. Mailand: Garzanti.

Genova, G. di (editor). 1997. L'uomo della provvidenza. Iconografia del Duce 1923-1945. Bologna: Bora. 
Gentile, E. [1993] 2003. Il culto del Littorio. La sacralizzazione della politica nell'Italia fascista. Rome: Laterza.

Kessel, L. 1995. Festarchitektur in Turin zwischen 1713 und 1773. Repräsentationsformen in einem jungen Königtum. München: scaneg.

Klinkhammer, L. 2003. Mussolinis Italien zwischen Staat, Kirche und Religion. In Zwischen Politik und Religion. Studien zur Entstehung, Existenz und Wirkung des Totalitarismus, edited by K. Hildebrand, 73-90. München: Oldenbourg.

Krauter, A. 1997. Die Schriften Paul Scheerbarts und der Lichtdom von Albert Speer. "Das grosse Licht", $\mathrm{PhD}$, Heidelberg.

Ludwig, E. 1932. Mussolinis Gespräche mit Emil Ludwig, Berlin, Wien and Leipzig.

Marchi, V. 1997. Elevare l'anima trascinandola nel regno mistico. In Architetture pirotecniche. Marchi, Scritti di Architettura. Volume 2, edited by E. Godoli and M. Giacomelli, 71-79. Florenz: Octavo.

Marra, L. 2000. Anni Santi 1300-2000 (not published): Fondazione Lions clubs per la solidarietà.

Melchiori, A. 1935. Elementi di cultura fascista ( $3^{\text {rd }}$ Edition). Rome.

Mosse, G. L. [1975] 1993. Die Nationalisierung der Massen. Politische Symbolik und Massenbewegungen von den Befreiungskriegen bis zum Dritten Reich. Frankfurt am Main: Campus.

Nützenadel, A. 2000. Staats- und Parteifeiern im faschistischen Italien. In Inszenierungen des Nationalstaats. Politische Feiern in Italien und Deutschland seit 1860/71, edited by S. Behrenbeck and A. Nützenadel, 127-147. Köln: SH 2000.

PNF [Partito Nazionale Fascista]. 1939. Il secondo libro del fascista. Rome.

Randone, E. 1933. Architettura ed illuminazione. La Rivista Illustrata del Popolo d'Italia (September): 41-45.

Speer, A. 1969. Erinnerungen. Frankfurt am Main: Propyläen.

Speer, A. 1979. Technik und Macht, edited by A. Reif. Esslingen am Neckar: Bechtle.

Taylor, B. 1996. Geballte photographische Wirkung. Malerei und ikonenhafte Überhöhung. In Kunst und Macht im Europa der Diktatoren 1930 bis 1945, edited by D. Ades, T. Benton, D. Elliot and I. B. White, 249-252. Stuttgart: Oktagon.

Ufficio Propaganda del Partito Nazionale Fascista (editor). 1923. Il Fascismo. Raccolta di aforismi e temi per propaganda compilata da M. Leva. Rome: Tipografia Selecta. 
Vercelloni, V. 1989. La storia del paesaggio urbano di Milano. Mailand: Edizioni L'Archivolto.

Vorstand der Kulturstiftung DessauWörlitz (editor). 2005. Der Vulkan im Wörlitzer Park. Berlin: Nicolai.

Werckmeister, O. K. 2005. Der Medusa-Effekt. Politische Bildstrategien seit dem 11. September 2001. Berlin: form + zweck. 
Figure 6: Installation of the illumination on the occasion of the anniversary of the March on Rome, October $28^{\text {th }}, 1933$

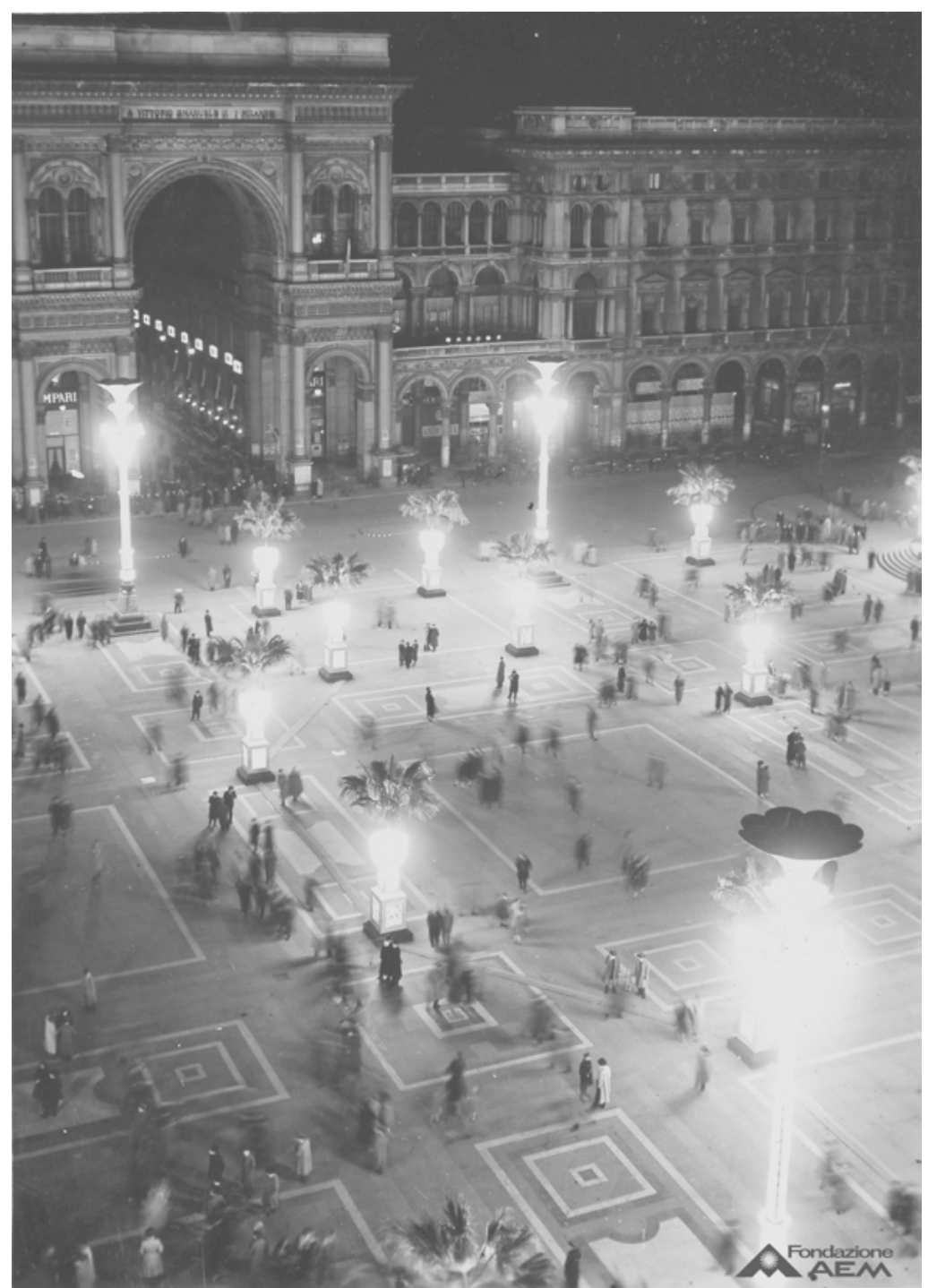

Source: AEM (Azienda Elettrica Municipale), Archivio Fotografico 
Figure 7: Illumination on the occasion of the anniversary of the March on Rome, October $28^{\text {th }}, 1932$

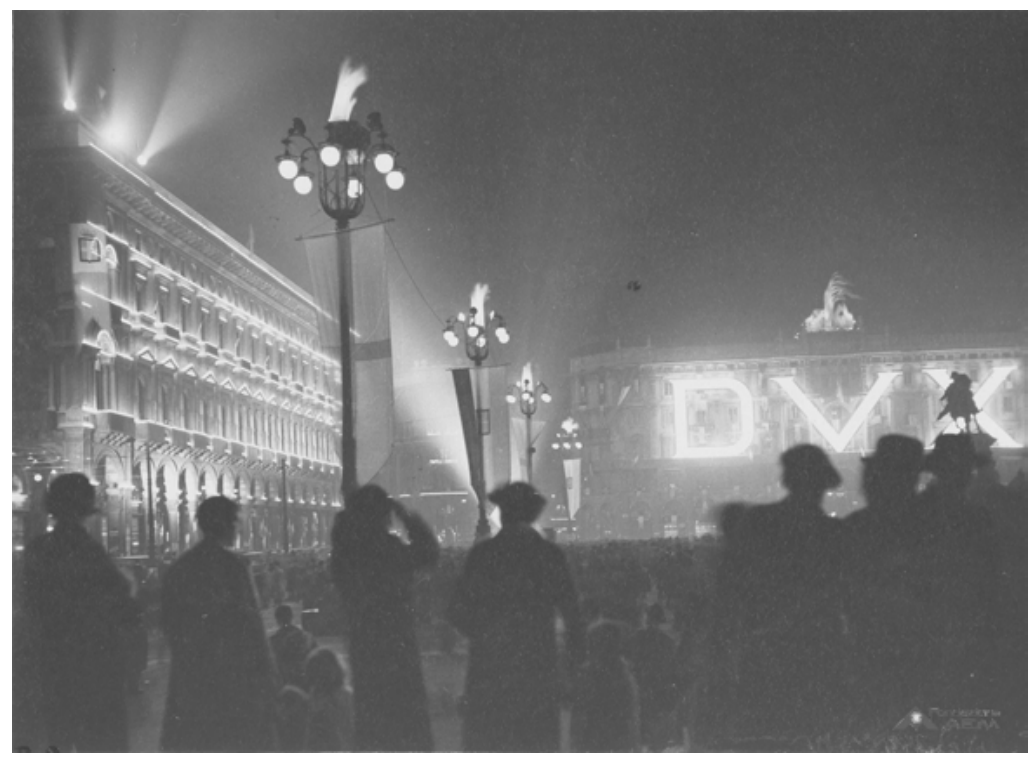

Source: AEM (Azienda Elettrica Municipale), Archivio Fotografico

Figure 8: Illumination on the occasion of the anniversary of the March on Rome, October $28^{\text {th }}, 1934$

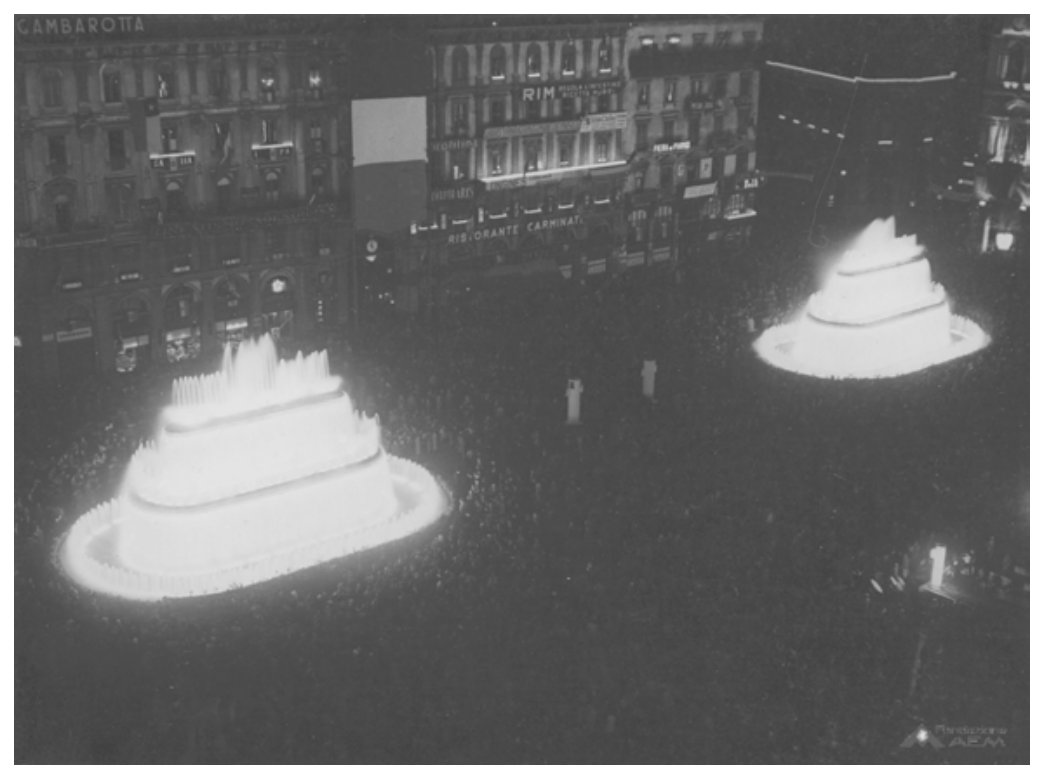

Source: AEM (Azienda Elettrica Municipale), Archivio Fotografico 
Figure 9: Illumination on the occasion of the anniversary of the March on Rome, October $28^{\text {th }}, 1936$

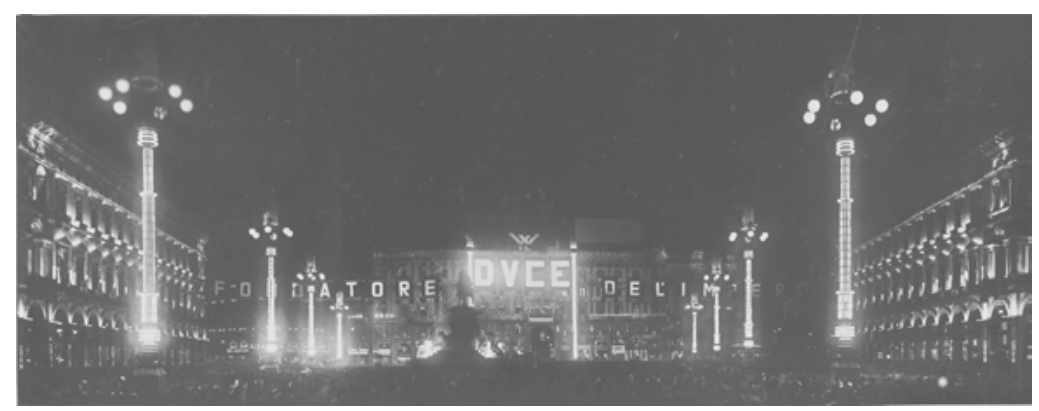

Source: AEM (Azienda Elettrica Municipale), Archivio Fotografico 
Figure 10: Vincenzo Carrese, “Milano saluta il Duce", photography, October $28^{\text {th }}$, 1933

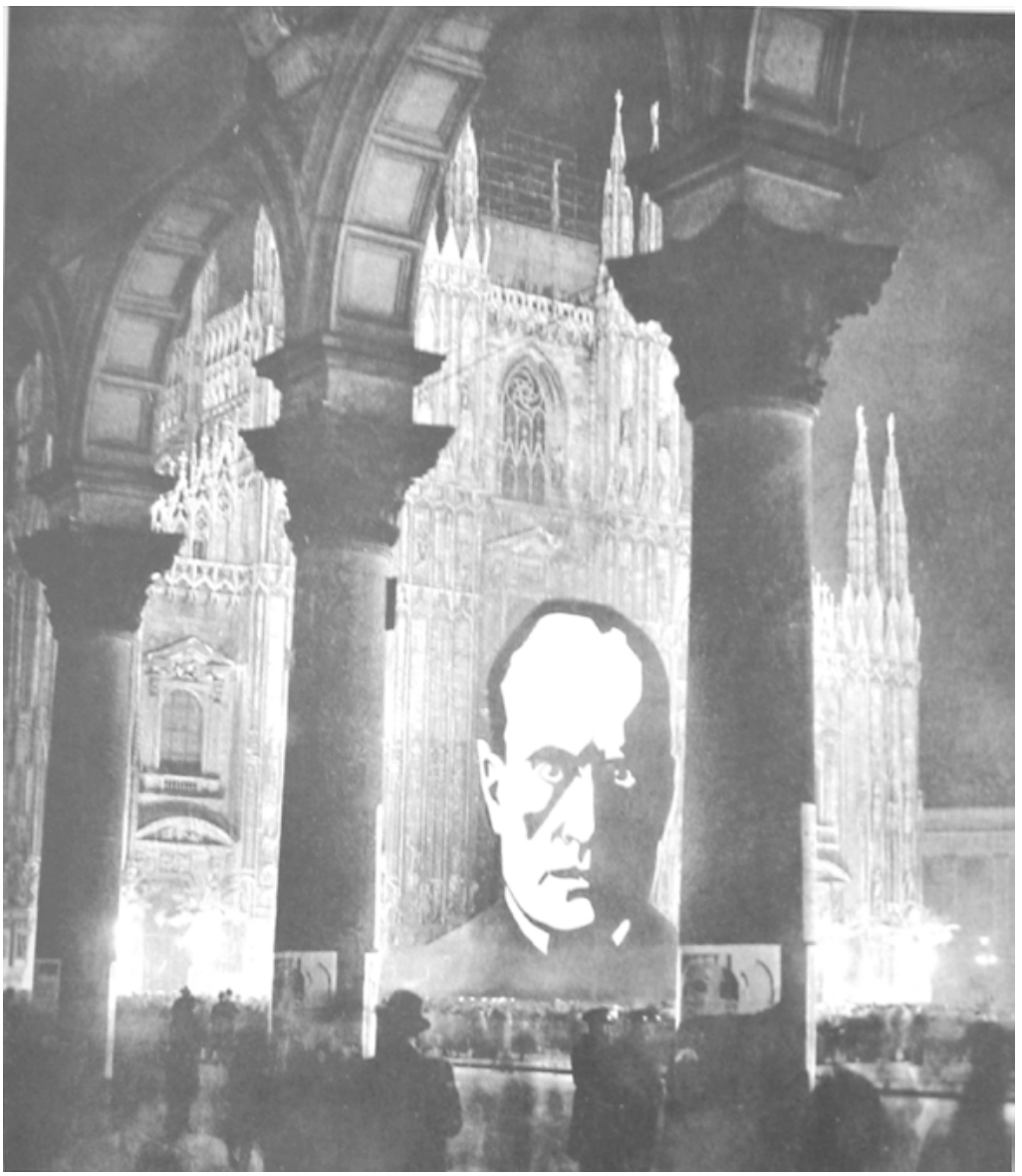

Source: Rivista Illustrata del "Popolo d'Italia”, November, 1933: 13 
Figure 11: Ceramic plate, ca. 1926

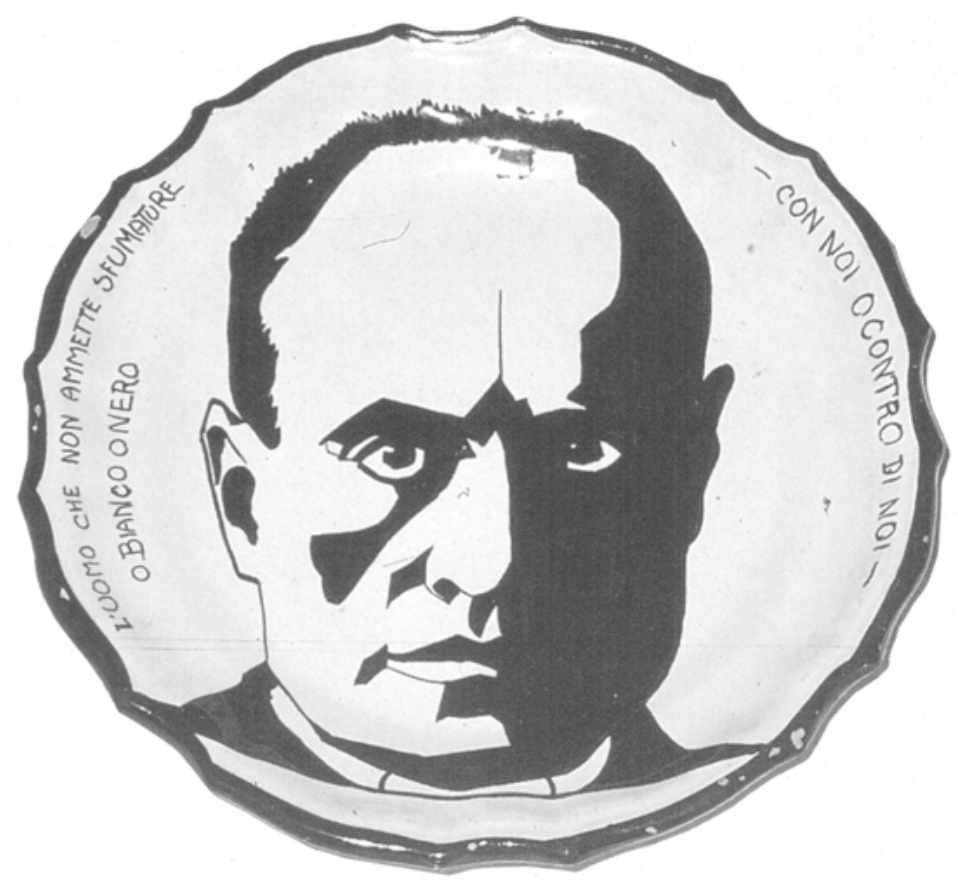


Figure 12: Pier Maria Bardi, "Origini"



Source: Quadrante, October, 1933: 5 
Figure 13: Illumination on the occasion of the anniversary of the March on Rome, October $28^{\text {th }}, 1933$



Source: AEM (Azienda Elettrica Municipale), Archivio Fotografico 
Figure 14: Mario Stroppa, "La piazza del Duomo allestita per la visita del Duce", pencil on paper, $36 \times 78 \mathrm{~cm}, 1932$

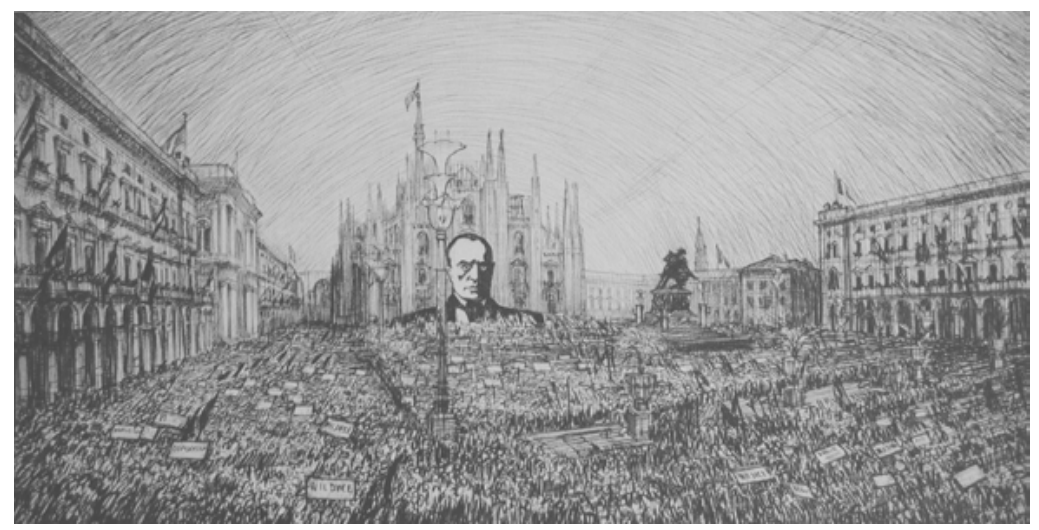

Source: Virgilio Vercelloni, La storia del paesaggio urbano di Milano, Mailand: Edizioni L'Archivolto 1989: 55

Figure 15: Anti-aircraft beams on the Zeppelin field, 1937

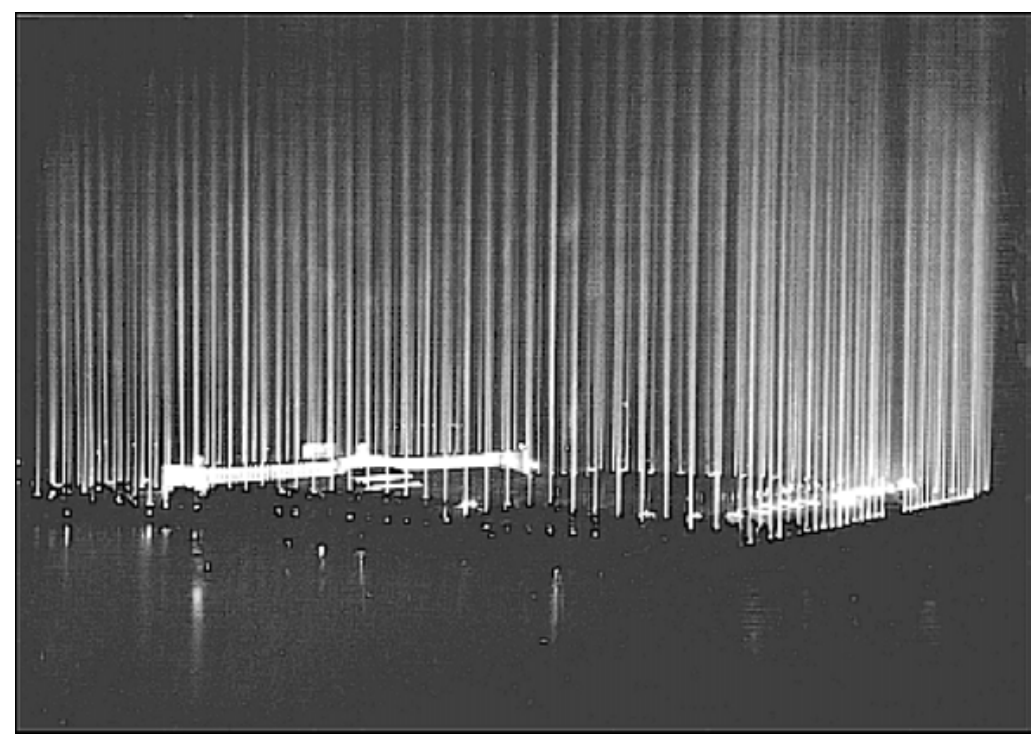

Source: Centrum Industriekultur Nürnberg 1992: 66. 
Figure 16: Ferruccio Vecchi, "L'Impero balza dalla mente del Duce”, 1939-40



Source: Genova 1997: 25. 
Figure 17: Gustav Klutsis, monumental photographies of Lenin and Stalin for May $1^{\text {st }}, 1932$



Source: Taylor, B. 1996: 249. 
Figure 18: Russian Icons, School of Dionissij, The Saints John Chrysostom and Basili the Great, $16^{\text {th }}$ century
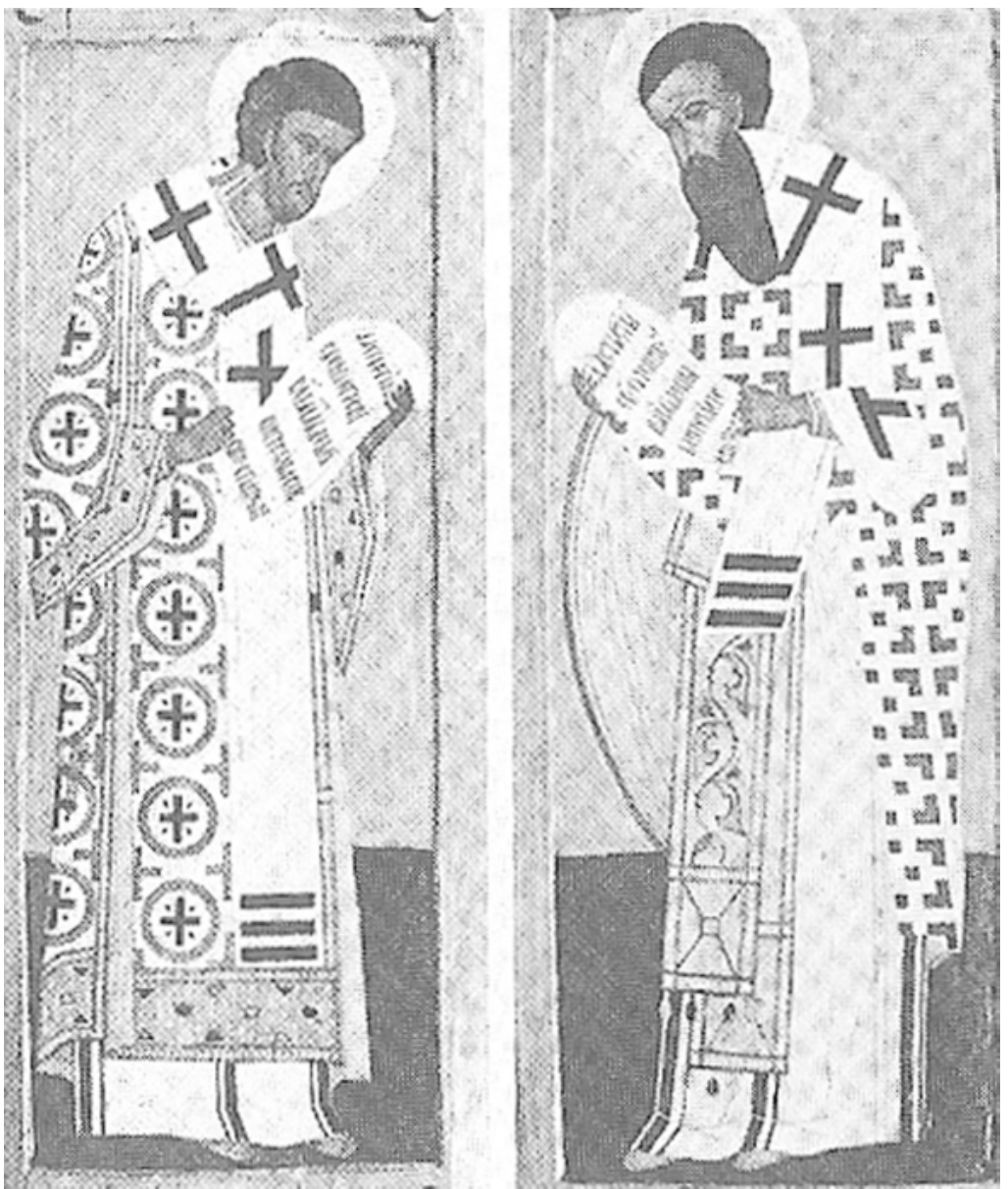

Source: Taylor 1996: 249. 
Figure 19: Illumination on the occasion of the anniversary of the March on Rome, October 28 ${ }^{\text {th }}, 1933$.

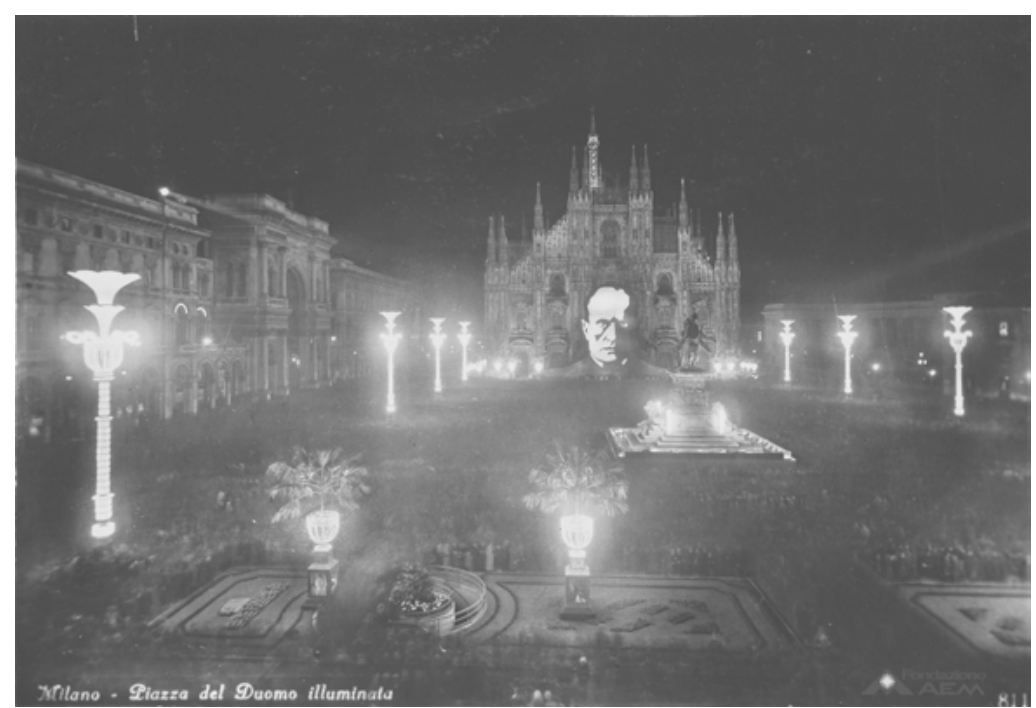

Source: AEM (Azienda Elettrica Municipale), Archivio Fotografico 